\title{
Sinobronkitis pada Anak
}

\author{
Noenoeng Rahajoe
}

Batuk kronik berulang (BKB) merupakan masalah yang sering dijumpai dalam praktek sehari-hari di bidang kesehatan anak. Batuk kronik berulang adalah batuk yang berlangsung hampir tiap hari minimal 2 minggu berturut-turut dan atau berulang paling sedikit 3 episode dalam 3 bulan. Seluruh bagian dari sistem respiratorik - mulai dari hidung hingga paru - merupakan satu kesatuan fungsional. Gangguan saluran napas atas dapat menyebabkan atau disertai dengan gangguan saluran napas bawah dan sebaliknya. Ada hubungan timbal balik antara sinusitis dengan bronkitis, yang disebut sebagai sinobronkitis, bronkosinusitis, atau sindrom sinobronkial. Sinobronkitis dapat mengenai pasien dewasa maupun anak. Sinusitis adalah proses inflamasi pada mukosa sinus paranasalis yang disebabkan oleh infeksi maupun non infeksi. Dalam patofisiologi sinusitis ada 3 hal yang berperan yaitu (1) patensi ostium, (2) fungsi mukosilier, dan (3) kualitas sekret. Patogenesis sinusitis umumnya berhubungan dengan sumbatan pada ostium, yang didahului oleh infeksi (virus, bakteri, atau jamur), alergi, atau kelainan anatomi. Berbeda dengan orang dewasa, gejala sinusitis pada anak tidak khas. Kuman patogen pada anak sama dengan yang didapatkan pada orang dewasa, yaitu Streptococcus pneumoniae, Haemophilus influenzae, dan Moraxella catharrhalis. Sinusitis sering mengikuti infeksi saluran napas atas akut oleh virus. Sinusitis sering didapatkan bersama dengan asma, hal ini dikaitkan dengan adanya postnasal drip, peningkatan blokade adregenik beta, atau refleks nasobronkial melalui saraf vagus. Kelainan radiologis yang dapat ditemukan pada sinusitis adalah air fluid level, perselubungan, atau penebalan mukosa. Walaupun belum ada penelitian tersamar ganda dengan kelompok kontrol, namun antibiotik yang dapat digunakan untuk mengobati sinusitis adalah amoksisilin, amoksisilin-klavulanat, kotrimoksazol, eritromisin-sulfisoksazol, atau sefalosporin, selama minimal 3 minggu.

Kata kunci: batuk kronik berulang, infeksi - alergi - kelainan anatomi

B atuk sebagai suatu gejala merupakan masalah yang sering dijumpai dalam praktek seharihari di bidang kesehatan anak, terutama bila gejala tersebut menjadi berulang dan atau kronik. Pada KONIKA V tahun 1981 di Medan

Staf pengajar sub-bagian Pulmonologi Bagian Ilmu Kesehatan Anak, Fakultas Kedokteran Universitas Indonesia - Rumah Sakit Cipto Mangunkusumo Jakarta.

Alamat korespondensi:

Dr. Noenoeng Rahajoe, Sp.A(K)

Bagian Ilmu Kesehatan Anak FKUI-RSCM, Jl. Salemba no. 6 Jakarta 10430. Tel.: 021-391 6043, 314 8930. Fax.: 3913982. disepakati bahwa batuk kronik dan berulang (BKB) adalah suatu keadaan klinis yang disebabkan oleh berbagai etiologi dengan gejala batuk yang berlangsung sekurang-kurangnya 2 minggu berturut-turut dan atau berulang paling sedikit 3 episode dalam 3 bulan dengan atau tanpa disertai gejala respiratorik atau non respiratorik lainnya. ${ }^{1}$

Di Poliklinik Pulmonologi IKA FKUI-RSCM, didapatkan 823 pasien baru BKB dari 2014 pasien kunjungan baru. Dari 823 pasien BKB, 321 berusia di atas 5 tahun dan 73 diantaranya menderita sinusitis. Terdapat hubungan yang erat antara infeksi saluran napas atas dan bawah, khususnya kelainan sinus dan paru. 
Hidung, nasofaring dan saluran napas bagian bawah merupakan satu kesatuan fungsional yang saling berhubungan secara timbal balik, sehingga setiap gangguan saluran napas bagian atas dapat menyebabkan atau disertai gangguan pada saluran napas bagian bawah atau sebaliknya. Ada hubungan antara bronkitis dan sinusitis, dan ini disebut sebagai sinobronkitis, bronkosinusitis atau sindrom sinobronkial.

Sinobronkitis dapat mengenai semua kelompok umur baik anak maupun orang dewasa. Anak-anak diperkirakan setiap tahun rata-rata mengalami 6-8 kali infeksi saluran napas atas dibandingkan orang dewasa yang hanya $2-3$ kali. Diperkirakan $0,5-5 \%{ }^{2}$ atau $5-$ $10 \%{ }^{3}$ infeksi saluran napas atas mempunyai komplikasi sinusitis, sehingga sinusitis pada anak mungkin lebih banyak ditemukan.

Pada makalah ini akan dibicarakan beberapa masalah mengenai penatalaksanaan sinobronkitis pada anak.

\section{Sinusitis}

Pada makalah ini yang dimaksud sinusitis adalah suatu proses inflamasi pada mukosa sinus paranasalis baik yang disebabkan infeksi maupun non-infeksi.

\section{Patofisiologi}

Untuk mengetahui patofisiologi sinusitis terdapat 3 hal yang harus diperhatikan yaitu (1) patensi ostium, (2) fungsi mukosilier, (3) kualitas sekret. Terhambatnya sekresi sekret sinus paranasalis dapat disebabkan oleh obstruksi ostium, gangguan fungsi silia atau produksi yang berlebihan atau perubahan viskositas sekret, diikuti dengan infeksi sekunder sehingga terjadi peradangan mukosa sinus paranasal.

Patogenesis sinusitis umumnya berhubungan dengan sumbatan pada ostium. Hal ini didahului oleh infeksi, alergi, kelainan anatomi atau edema mukosa hidung yang akan mengganggu ventilasi dan drainase sinus. Umumnya para peneliti sependapat bahwa buntunya meatus ostium merupakan mekanisme patofisiologi primer terjadinya sinusitis. Obstruksi itu dapat disebabkan oleh variasi anatomi atau inflamasi dan kombinasi keduanya sering menyebabkan infeksi sinus paranasalis yang berulang atau kronik. ${ }^{4}$

Infeksi virus, bakteri dan jamur akan mengganggu kerja sel mukosa yang melapisi sinus. Keadaan di atas menyebabkan penimbunan sekret yang diikuti dengan multiplikasi bakteri dan masuknya sel-sel inflamasi yang mengubah mukus menjadi mukopus. Sel-sel mati yang dihasilkan dari multiplikasi virus dan terlepasnya epitel saluran pernapasan merupakan bagian perjalanan penyakit ini. Biasanya regenerasi mukosa segera terjadi dan penyakit menyembuh, tetapi apabila regenerasi tidak berhasil dan proses berlanjut, maka kerusakan epitel tidak bisa diperbaiki. Hal ini akan mengakibatkan penebalan mukosa dan terjadinya mukokel atau polip. ${ }^{5}$

Kuman patogen yang didapatkan pada anak sama dengan yang didapatkan pada orang dewasa. Penyebab terbanyak adalah bakteri dan hampir setengah dari pasien sinusitis disebabkan Streptococcus pneumoniae, Haemophilus influenzae dan Branhamella catarrhalis. ${ }^{6-8}$ Kadang-kadang ditemukan bakteri anaerob pada cairan sinus yang diisolasi, begitu pula ditemukan rhinovirus, virus influenza dan virus parainfluenza. ' Tabel 1 memperlihatkan dari 79 aspirat yang diambil pada 50 anak, dengan sinusitis akut didapatkan 58 aspirat yang mempunyai kultur positif, dengan jenis bakteri terbanyak adalah Streptococcus pneumoniae, Branhamella catarrhalis, dan Haemophilus influenzae.

Tabel 2. Memperlihatkan jenis bakteri dari 52 aspirat pada 40 anak dengan sinusitis subakut. Bakteri terbanyak yang ditemukan sama seperti pada sinusitis akut. Bakteri yang ditemukan pada sinusitis kronik dapat dilihat pada Tabel 3.

Adanya bakteri anaerob berhubungan erat dengan

Tabel 1. Jenis bakteri yang ditemukan pada 79 aspirat sinus dari 50 anak dengan sinusitis akut ${ }^{9}$

\begin{tabular}{lr}
\hline Spesies bakteri & Jumlah \\
\hline Streptococcus pneumoniae & 22 \\
Branhamella catarrhalis & 15 \\
Haemophilus influenzae & 15 \\
Elkenella coorodens & 1 \\
Group A streptococcus & 1 \\
Group C streptococcus & 1 \\
Alpha-hemolytic streptococcus & 1 \\
Peptostreptococcus & 1 \\
Morraxella & 1 \\
\hline
\end{tabular}

Dikutip dari Wald (1994) 
Tabel 2. Jenis bakteri pada 52 aspirat, 40 anak dengan sinusitis subakut ${ }^{10}$

\begin{tabular}{lr}
\hline Spesies bakteri & Jumlah \\
\hline Streptococcus pneumoniae & 12 \\
Branhamella catarrhalis & 11 \\
Haemophilus influenzae & 8 \\
Streptococcus pyogenes & 2 \\
Streptococcus viridans & 1 \\
Morraxella & 1 \\
\hline
\end{tabular}

Dikutip dari Wald (1989) rendahnya tekanan oksigen dalam rongga sinus. Pada infeksi virus atau proses inflamasi lainnya, terjadi edema submukosa dan inflitrasi sel radang yang akan melemahkan kerja silia sehingga mengakibatkan terjadinya penumpukan sekret serta mempermudah timbulnya infeksi sekunder. Perlu diingat bahwa hasil biakan usap tenggorokan tidak selalu sesuai dengan hasil biakan aspirat sinus. ${ }^{12}$

Jenis bakteri dari sekret sinus di RSCM ternyata berbeda dengan hasil di luar negeri. Tabel 4 memperlihatkan jenis kuman yang ditentukan dan dilakukan berupa adenoid, sekret sinus dan sekret bronkus.

Tabel 3. Jenis bakteri pada sinus maksilaris, dari 20 anak dengan sinusitis kronik ${ }^{11}$

\begin{tabular}{|c|c|c|}
\hline Spesies bakteri & Jumlah sinus & Bakteri Positif \\
\hline - $\quad$ Bakteri aerobes & 30 & - \\
\hline - $\quad$ Pseudomonas aeruginosa & 13 & 7 \\
\hline - Haemophillus influenzae & 10 & 5 \\
\hline - $\quad$ Streptococcus haemolyticus (termasuk Streptococcus microaerophilic) & 5 & 3 \\
\hline - Escherichia coli & 5 & 4 \\
\hline - $\quad$ Staphyllococcus aureus & 1 & 1 \\
\hline - Bakteri anaerobes & 5 & - \\
\hline - $\quad$ Spesies Peptostreptococcus & 2 & - \\
\hline - $\quad$ Boraxellla oralis & 1 & - \\
\hline - $\quad$ P. acnes & 1 & - \\
\hline - $\quad$ Bakteri Gram negatif lain & 1 & 1 \\
\hline
\end{tabular}

Dikutip dari Shapiro ED (1982)

Tabel 4. Jenis bakteri dari adenoid, sinus dan bronkus

\begin{tabular}{lccc}
\hline \multirow{2}{*}{ Bakteri } & \multicolumn{3}{c}{ Asal bahan pemeriksaan } \\
\cline { 2 - 4 } & Adenoid & Sinus & Bronkus \\
\hline Steril & 7 & 5 & 8 \\
Pseudomonas & 3 & 5 & 4 \\
Streptococcus hemolyticus & 1 & 1 & 1 \\
Streptococcus anhemolyticus & 2 & 1 & - \\
Aerobacter aerogenes & 2 & - & 1 \\
Staphyllococcus hemolyticus & 1 & 3 & - \\
Sporoformis & - & 1 & - \\
Proteus mirabilis & - & - & 1 \\
\end{tabular}




\section{Beberapa Penyakit yang Berhubungan dengan Sinusitis}

\section{Infeksi Saluran Napas Akut Atas ${ }^{2-3}$}

Sinusitis sering mengikuti infeksi saluran napas akut (ISPA) atas yang disebabkan oleh virus yang sering terjadi pada anak. Terdapat 2 keadaan yang harus dicurigai adanya infeksi sekunder pada ISPA atas yang disebabkan oleh virus yaitu:

1. Bila ISPA atas berlangsung 10 hari atau lebih tanpa perbaikan yang jelas. Biasanya didapatkan sekret hidung dan batuk yang menetap walaupun keadaan pasien tidak nampak sakit.

2. Gejala ISPA atas lebih berat dari biasanya, misalnya demam yang tinggi, sekret hidung yang purulen, pembengkakan periorbital, dan nyeri muka.

Diperkirakan $0,5-5 \%^{2}$ atau $5-10 \%{ }^{3}$ ISPA atas yang akan melanjut menjadi sinusitis.

\section{Rinitis Alergika}

Seperti pada reaksi alergi umumnya bila sel mast mukosa atau basofil terangsang oleh alergen maka dapat terjadi reaksi nasal tipe cepat maupun tipe lambat. Akibat reaksi tersebut maka akan menyebabkan rasa gatal, udema mukosa, hipersekresi atau kerusakan mukosa sehingga mengganggu transport mukosilier. Hal ini akan memudahkan terjadinya sinusitis.

\section{Rinitis non Alergika}

Rinitis non alergika adalah rinitis yang tidak berhubungan dengan alergi yang dibuktikan dengan hasil uji kulit alergi yang negatif dan nilai IgE yang normal.

Rinitis non alergika dapat disebabkan oleh rangsangan non spesifik pada sel mast, pelepasan neuropeptida sensori lokal, reaksi vaskuler yang berlebihan atau kombinasinya. Akibat hal di atas akan merusak mukosa membran yaitu sel goblet menjadi hilang atau sebaliknya sel epitel sebagian besar terdiri dari sel goblet, jumlah sel bersilia sangat berkurang atau bentuknya berubah, dan mukosa banyak yang terlepas, hiperplasia atau adanya mikro abses.

\section{Asma}

Sinusitis merupakan penyakit yang sering menyertai asma, terdapat 3 hipotesis yang melibatkan sinusitis pada patogenesis asma yaitu: ${ }^{13}$

1. Postnasal drip menyebabkan inflamasi pada mukosa bronkus dan peningkatan hiperreaktivitas bronkus.

2. Infeksi pada saluran napas meningkatkan blokase beta adrenergik. Pada asma telah terjadi blokade parsial beta adrenergik. Kedua hal di atas akan meningkatkan blokade beta adrenergik atau dengan perkataan lain sinusitis akan lebih meningkatkan hiperreaktivitas bronkus.

3. Refleks nasobronkial melalui sistem saraf vagus. Rangsangan pada reseptor saraf di hidung dan sinus akan mengakibatkan spasme bronkus.

Selain ketiga hipotesis di atas, masih ada hipotesis lain yaitu terganggunya fungsi akomodasi hidung akibat pernapasan melalui mulut sering terjadi pada anak yang menderita sinusitis. Mekanisme di atas sama seperti pada asma yang dicetuskan oleh beban fisik. ${ }^{14}$ Terdapat kesamaan gambaran patologi antara sinusitis kronis dan asma. Penemuan ini menambah bukti adanya hubungan antara gangguan saluran napas bagian atas dan gangguan saluran napas bawah. Dengan memperhatikan hubungan-hubungan tersebut di atas maka dalam menanggulangi asma harus dipikirkan kemungkinan adanya kelainan saluran napas bagian atas yang mungkin memperberat asmanya. Pengobatan sinusitis terbukti memperbaiki asmanya (lihat Tabel 5). ${ }^{16}$

\section{Diagnosis}

Diagnosis sinusitis berdasarkan gambaran klinis, pemeriksaan fisis dan penunjang.

\section{Gambaran klinis}

Gambaran klinis sinobronkitis pada anak bervariasi, dapat berupa:

- Batuk ditemukan pada sebagian besar kasus, dapat berupa batuk kronik dan/atau berulang, iritatif terutama malam hari,

- Pilek yang berlangsung lama, sekret kental dan/ atau purulen,

- Post nasal drip

- Hidung rasa tersumbat oleh karena edema mukosa hidung, ditambah dengan adanya deviasi septum nasi, polip atau hipertrofi adenoid, 
Tabel 5. Karakteristik penyakit sebelum dan sesudah pengobatan sinusitis pada 48 anak $^{16}$

\begin{tabular}{lcccc}
\hline \multirow{2}{*}{ Karakteristik } & \multicolumn{2}{c}{ Sebelum } & \multicolumn{2}{c}{ Sesudah } \\
\cline { 2 - 5 } & Jumlah & $\%$ & Jumlah & $\%$ \\
\hline Batuk & 48 & 100 & 14 & 29 \\
Mengi & 48 & 100 & 7 & 15 \\
Pilek & 30 & 63 & 10 & 21 \\
Pemakaian bronkodilator & 48 & 100 & 10 & 21 \\
Uji fungsi paru normal n=30 & 0 & 0 & 20 & 67 \\
Radiologi sinus normal & 0 & 0 & 38 & 79 \\
\hline
\end{tabular}

Dikutip dari Rachelefsky (1984)

- Demam,

- Bernapas melalui mulut dan napas berbau.

- Nyeri sinus dan sakit kepala yang tidak jelas lokasinya, yang biasanya ditemukan pada anak besar,

- Tidur ngorok,

- Tanda radang kronis pada faring, tonsil dan adenoid.

Said, pada penelitiannya terhadap 52 kasus sinobronkitis yang berobat jalan di Polikinik Pulmonologi IKA FKUI-RSCM Jakarta, mendapatkan gejala klinis yang terbanyak adalah batuk kronik berulang (100\%) dan pilek lebih dari 7 hari (92,3\%). Gambaran klinis sinusitis pada anak umumnya adalah batuk, pilek dan hidung tersumbat, seperti terlihat pada Tabel 6.

Pada anak, gejala demam dan nyeri di daerah

Tabel 6. Presentasi gejala klinis sinusitis ${ }^{9,17,18}$

\begin{tabular}{lccc}
\hline Gejala & $\begin{array}{c}\text { Wald dkk } \\
(1981)\end{array}$ & $\begin{array}{c}\text { Said }^{17} \\
(1988)\end{array}$ & $\begin{array}{c}\text { Arruda dkk } \\
(1990)\end{array}$ \\
\hline Batuk & 80,0 & 100 & 100 \\
Pilek & 76,7 & 92,3 & 75,0 \\
Hidung tersumbat & 33,3 & 30,7 & 33,3 \\
Nyeri kepala & 30,0 & 17,3 & 8,3 \\
Nyeri sinus & 30,0 & - & - \\
Demam & 30,0 & - & - \\
Nyeri tenggorok & 23,3 & - & - \\
Fetor oris & 50,0 & - & - \\
& & & \\
\hline
\end{tabular}

muka lebih jarang dijumpai dibanding pada orang dewasa. ${ }^{5}$

\section{Pemeriksaan fisis}

Pada sinusitis, pemeriksaan fisis tidak khas; kadangkadang dapat dijumpai sekret nasal, kelainan pada septum, livide pada konka nasal, dan post nasal drip serta nyeri pada sinus.

\section{Pemeriksaan penunjang}

1. Non radiologik

- pemeriksaan sitologi nasal dijumpai eosinofil, polimorfonuklear, limfosit dan basofil.

- $\quad$ endoskopi serat optik.

- endoskopi rigid

2. Radiologik

- foto rontgen sinus, terdiri dari 3 proyeksi yaitu: Waters, berguna untuk mengevaluasi sinus maksilaris dan sinus frontalis, b) Caldwell, berguna untuk mengevaluasi sinus etmoidalis, c) Proyeksi lateral berguna untuk mengevaluasi ukuran adenoid, massa di nasofaring dan kelainan sfenoid.

- A-mode ultrasonography

- Computer tomography

- $\quad M R I$

Beberapa penulis menghubungkan antara kelainan radiologik dengan diketemukannya biakan bakteri dari aspirat sinus (Tabel 7). ${ }^{7,8,18}$ 


\section{Tatalaksana}

\section{Non medikamentosa}

Bahan-bahan yang merangsang mukosa secara alergenik maupun non alergenik yang dapat menimbulkan perubahan pada mukosa dan akhirnya dapat menimbulkan gangguan pada drainase sekret, perlu dihindari. Demikian pula faktor-faktor predisposisi yang lain perlu disingkirkan.

Tindakan pengendalian lingkungan lebih penting lagi karena alergi merupakan faktor predisposisi yang sering dijumpai. Nu'man D menemukan 27 dari 52 kasus yang dilaporkan $(51,9 \%)$ terdapat riwayat alergi dalam keluarganya. Jenis alergen yang menimbulkan reaksi uji kulit positif terutama berturut-turut sesuai dengan banyaknya debu rumah, makanan dan campuran. ${ }^{19}$ Siregar SP melaporkan 58 dari 94 anak dengan sinusitis $(62,5 \%)$ disertai dengan asma, asma dengan rhinitis dan $36(37,5 \%)$ rhinitis alergik. Riwayat alergi dalam keluarga ditemukan pada $77,5 \%$. Distribusi uji kulit ditemukan terutama berturut-turut sesuai dengan banyaknya debu rumah, makanan, binatang peliharaan dan jamur. ${ }^{20}$

\section{Medikamentosa}

a. Intranasal ${ }^{5}$

- Larutan garam faali. Larutan ini berguna untuk mengencerkan sekret, meringankan iritasi jaringan, melembabkan membran, mengurangi perdarahan, memperbaiki transport mukosilier dan memperbaiki penciuman.

- Vasokonstriktor (dekongestan) Dekongestan dibagi dalam golongan katekolamin (efinefrin, fenilefrin) yang terutama bekerja pada adrenoseptor alfa 1, dan derivat imidazol (napazolin, silometazolin 1\%), terutama bekerja pada adrenoseptor. Tujuan pemberian dekongestan ini untuk meningkatkan aerasi nasal dengan cara vasokonstriksi sehingga ostium terbuka dengan cepat dan dengan demikian memperbaiki drainase sekret. Pemberian obat ini dianjurkan hanya beberapa hari, guna menghindari terjadinya rinitis medikamentosa yang bahkan merupakan predisposisi terjadinya sinusitis. Di Subbagian Pulmonologi IKA FKUI-RSCM, pemberian obat dekongestan atas indikasi tertentu yaitu apabila sudah dengan pemberian garam faali masih belum ada perbaikan aerasi.

- Anti inflamasi

- Sodium kromoglikat. Merupakan inhibitor degranulasi sel mast yang kuat dan efektif. Penggunaan obat intranasal ini berguna dalam mengobati reaksi mukosa hidung yang disebabkan rangsangan alergen untuk mencegah reaksi cepat dan reaksi lambat.

- Steroid. Penambahan steroid intranasal di samping pemberian antibiotik merupakan pengobatan yang paling efektif. Pemberian ini akan mempercepat perbaikan pada gejala, mengurangi inflamasi intranasal, dan mempercepat perbaikan gambaran radiologis. ${ }^{21}$ Kunci keberhasilan jangka panjang penanggulangan sindrom sinobronkial anak terletak pada keberhasilan penanggulangan inflamasi sebagai penyebab dasarnya. $^{22}$

b. Oral

- Non steroid

- Bronkodilator. Dasar penggunaan obat bronkodilator adalah adanya hiperreaktivitas pada anak dengan sinusitis. Hiperreaktivitas pada sinusitis dapat oleh

Tabel 7. Hubungan antara gambaran radiologis dengan biakan bakteri positif (\%)

\begin{tabular}{lcccr}
\hline Peneliti & \multicolumn{3}{c}{ Kelainan radiologi } \\
\cline { 2 - 4 } & Garis udara air & Perselubungan & Penebalan mukosa & Normal \\
\hline Hamory dkk ('79) & $16 / 18(88,8)$ & $10 / 18(55,6)$ & $8 / 12(66,7)$ & $2 / 10(20)$ \\
Wald dkk ('89) & - & $32 / 52(61,5)$ & $18 / 52(34,6)$ & $2 / 52(3)$ \\
Arruda ('90) & - & $8 / 12(66,66)$ & - & $6 / 12(28,5)$ \\
\end{tabular}


karena asma yang menyertai sinusitis atau sinusitis itu sendiri dapat menyebabkan hiperreaktivitas. Untuk menanggulangi gejala yang disebabkan oleh hiperreaktivitas tersebut digunakan bronkodilator. Selain itu obat ini dapat meningkatkan transport mukosilier.

- Dekongestan. Jenis, indikasi dan cara kerja obat ini seperti juga yang dipakai dalam penggunaan intranasal.

- Antihistamin. Antihistamin oral digunakan sebagai bahan ajuvan dalam penatalaksanaan sinusitis. Pemberian antihistamin dalam tata laksana sinusitis nonalergi pada anak masih kontroversial. Bila antihistamin digunakan harus dengan hati-hati karena kemungkinan efek sampingnya dapat mengeringkan mukosa dan mengentalkan lendir.

- Steroid. Naspitz, ${ }^{5}$ menganjurkan pemberian kortikosteroid oral jangka pendek selama 1 minggu, yang diikuti dengan pemberian steroid intranasal selama 3 minggu.

- Antibiotik ${ }^{23,24}$ Antibiotika yang dipakai harus memenuhi syarat: sensitif terhadap kuman penyebab, kadar dalam mukosa sinus dan bronkus lebih tinggi dari kadar inhibisi minimum dari jenis kuman penyebab, cara pemberian mudah, efek samping sedikit dan obat tersedia dengan harga relatif murah. Antibiotik yang sering digunakan adalah amoksisilin, kotrimoksasol, sefalosporin dan makrolid.

1. Amoksisilin, merupakan obat pilihan untuk pasien sinusitis yang tidak mengalami komplikasi. Menggantikan kedudukan ampisilin di dalam pengobatan infeksi saluran napas atas akibat bakteri, karena absorbsinya dua kali lebih baik dan mempunyai waktu paruh yang lebih panjang. Merupakan obat yang efektif pada sebagian besar pasien, relatif murah dan aman. Kerugian amoksisilin adalah lemah terhadap beta-laktamase yang dihasilkan oleh $H$. influenzae dan $M$. catarrhalis.

2. Amoksisilin dan potassium klavulanat, telah dikembangkan dan dipasarkan pada tahun 1985. Potasium klavulanat adalah garam dari asam klavulanat, merupakan beta-laktam yang dengan aktivitas sedikit melawan bakteri patogen tetapi mampu secara efektif menginhibisi enzim betalaktamase.

3. Trimetoprim-sulfametoksazol (TMP-SMX), merupakan kombinasi 2 asam folat antagonis, merupakan antimikroba berspektrum luas. Kombinasi obat ini kurang efektif terhadap Streptococus grup A. Pada sinusitis orang dewasa, keberhasilan obat ini mencapai 95\%. Etiologi sinusitis pada dewasa hampir sama dengan sinusitis pada anak.

4. Eritromisin dan sulfisoksazol, merupakan kombinasi oral untuk pengobatan sinusitis pada anak. Dari kepustakaan didapatkan hasil yang berhasil (21 dari 22 anak sinusitis maksilaris) 95\%. ${ }^{18}$ Eritromisin efektif terhadap kokus Gram positif tetapi tidak dapat digunakan sendiri untuk sinusitis akut karena tidak adekuat terhadap $H$. influenzae yang merupakan salah satu penyebab pada semua umur.

5. Golongan sefalosporin merupakan antimikroba yang strukturnya mirip dengan golongan penisilin dan termasuk antimikroba beta-laktam. Sefaklor merupakan generasi kedua dari sefaloporin, obat oral untuk infeksi saluran napas pada anak dan rasanya enak. Kelemahannya adalah dalam aktivitasnya terhadap beta-laktamase yang diproduksi oleh sebagian besar strain $M$. catarrhalis dan beberapa strain $H$. influenzae, diberikan 3 kali dalam sehari.

Lama pemberian antibiotik belum pernah diteliti secara sistematis. Secara empiris antibiotika dapat diberikan selama 10-14 hari. Mukosa sinus baru sempurna lagi kurang lebih setelah 3-4 minggu setelah menderita sinusitis. Karena itu sangat disarankan untuk memberikan antibiotika selama 3-4 minggu untuk mengurangi kemungkinan berulangnya sinusitis. Hasil pengobatan sinusitis dengan beberapa antibiotika terlihat pada Tabel 8 .

Pada tabel di atas terlihat bahwa sulfamethosazol + trimethropin hanya terdapat perbaikan klinis sebanyak $62 \%$, tetapi peneliti lain mendapatkan perbaikan secara bakteriologis pada orang dewasa sebesar 95\%.2 Mengingat etiologi sinusitis pada anak sama dengan dewasa, maka pengobatan ini dapat dipertimbangkan. Di Subbagian Pulmonologi IKA FKUI-RSCM dengan pengobatan amoksisilin $50 \mathrm{mg} / \mathrm{kgbb} /$ hari dibagi dalam 3 dosis pada 36 kasus dengan sinobronkitis. Secara klinis didapatkan $88,9 \%$ sembuh atau perbaikan dan $80,5 \%$ secara 
Sari Pediatri, Vol. 2, No. 3, Desember 2000

Tabel 8. Hasil pengobatan dengan antibiotik pada sinusitis

\begin{tabular}{llc}
\hline \multirow{2}{*}{ Antibiotik } & \multicolumn{2}{l}{ Perbaikan klinis } \\
\cline { 2 - 3 } & Jumlah & $\%$ \\
\hline Amoksisilin & $22 / 27$ & 81 \\
Sefaklor & $18 / 23$ & 78 \\
Amoksisilin+potasium klavulanat & $16 / 17$ & 93 \\
Eritromisin+sulfisoxazol & $21 / 22$ & 95 \\
Eritromisin etilsusinat & $8 / 22$ & 36 \\
Sulfamethosazol+trimethropin & $13 / 21$ & 62 \\
\hline
\end{tabular}

Dikutip dari Wald $(1992)^{24}$

radiologis; sedangkan rontgen paru $47,3 \%$ perbaikan dan yang lainnya menetap. ${ }^{19}$

\section{Tindakan operatif ${ }^{25}$}

\section{Adenoektomi}

Terdapat hubungan antara hipertrofi adenoid dengan sinusitis, jika adenoid sangat besar akan terjadi stasis dari aliran sekret dan terjadi sinusitis kronik atau berulang walaupun telah diberikan pengobatan medikamentosa yang adekuat dan diperpanjang maka tindakan ini terindikasi.

\section{Antral lavage}

Tindakan ini terindikasi bila dengan pendekatan konservatif selama 4-6 minggu tidak berhasil. Pencucian dan irigasi rongga sinus pada pengelolaan sinusitis kronik mulai diragukan kegunaannya setelah adanya antibiotik yang modern dan steroid nasal yang kuat. ${ }^{26}$ Apalagi bila pengobatan medikamentosa digunakan secara optimal dan agresif maka tindakan bedah jarang diperlukan. ${ }^{27,28}$

\section{Bedah sinus endoskopik}

Bedah sinus endoskopik ini di tangan ahli THT yang mahir sangat berguna dan makin populer. Tindakan ini dapat memperbaiki klirens mukosilier bahkan dalam waktu yang singkat yaitu 10-30 menit pascatindakan. Padahal dalam waktu sesingkat itu tidak mungkin mukosa yang hilang atau rusak sudah pulih.
Ini menunjukkan bahwa tetap terbukanya ostium sinus merupakan hal yang penting untuk memperbaiki klirens mukosilier. ${ }^{29}$

\section{Operasi Caldwell-Luc}

Tindakan ini merupakan pertimbangan terakhir.

\section{Indikasi bedah}

Penanggulangan dengan cara pembedahan perlu dipertimbangkan apabila

1. Sinusitis kronis atau berulang dengan eksaserbasi akut dan telah gagal dengan pemberian antibiotika yang adekuat dan diperpanjang, penanggulangan lingkungan dan kortikosteroid intranasal.

2. Sinusitis kronis dan menderita juga perburukan penyakit paru atau penyakit infeksi paru yang dapat terkendali dengan baik ketika sinusitisnya dalam keadaan remisi.

3. Pasien asma yang tercetus serangannya oleh sinusitis berulang.

Pemeriksaan yang memastikan adanya kelainan pada meatus ostium kompleks misalnya dengan $C T$ scan perlu dilakukan karena bila tidak ada kelainan merupakan kontraindikasi relatif untuk tindakan pembedahan. Pemeriksaan dengan $C T$ scan bahkan lebih berguna dilakukan pada keadaan tenang maupun sedang kambuh, dalam keadaan tenang pengaruh inflamasi akut berkurang dengan demikian penemuan daerah dengan penyempitan anatomik atau daerah dengan kerusakan yang menetap dan menjadi dasar penyakit dapat ditemukan. Penemuan ini dapat menjadi petunjuk bagi ahli THT untuk diperbaiki pada operasi. ${ }^{30}$

\section{Kesimpulan}

Apabila seorang anak menunjukkan gejala saluran napas berkepanjangan atau BKB perlu diingat kemungkinan sinobronkitis sebagai salah satu sebabnya. Dalam pengobatan sinusitis maka amoksisilin merupakan antibiotika pilihan dan diberikan 34 minggu. Apabila tidak berhasil atau terdapat hipersensitivitas terhadap amoksisilin, maka dapat dipertimbangkan sulfometoksazol+ trimetoprim, atau golongan makrolid. Penggunaan kombinasi amoksisilin + potasium klavulanat diberikan apabila gagal 
dan tidak hipersensitif terhadap amoksisilin. Selain antibiotik digunakan juga bronkodilator. Pembersihan jalan napas bagian atas dengan larutan garam faali dan penghindaran pencetus yang alergenik maupun nonalergenik perlu dilaksanakan. Steroid oral jangka pendek yang disertai dengan steroid intranasal untuk beberapa minggu perlu dipertimbangkan. Perlu diupayakan terbukanya meatus optium dan upayaupaya lain yang penting untuk mengembalikan dan mempertahankan kerja klirens mukosilier yang baik. Karena inflamasi merupakan kelainan dasar dari sebagian besar kasus sinobronkitis maka penghindaran pencetus merupakan tindakan yang penting dan tak terpisahkan dari tindakan-tindakan lainnya. Kelainan anatomik atau predisposisi yang lain perlu diperhatikan dan diambil tindakan yang sesuai. Terdapatnya keterkaitan antara alat napas bawah dengan atas maka gangguan pada kedua bagian alat napas itu sering berhubungan dan perlu diatasi secara bersamaan untuk meningkatkan keberhasilan penatalaksanaannya.

\section{Daftar Pustaka}

1. Unit Kerja Koordinasi Pulmonologi. Kesepakatan bersama definisi batuk kronik dan/atau berulang. Disampaikan pada Kongres Nasional Ilmu Kesehatan Anak V, Medan, 1981.

2. Gwaltney JM, Sydnor A, Sande MA. Etiologi and antimicrobial treatment of acute sinusitis. Ann Otol Rhinol Laryngeal 1981; 90:68-71.

3. Wald ER, Guerra N, Byers C. Upper respiratory tract infection in young children: duration of and frequency of complications. Pediatrics 1991; 87:129-33.

4. Wagenmann $\mathrm{M}$ et al. Anatomic and physiologic considerations in sinusitis. J Allergy Clin Immunol 1992; 90:419-23.

5. Naspitz CK, Tinkelmand DG. Childhood rhinitis and sinusitis. Pathophysiology and treatment. New York: Marcel Dekker 1990; p.193-272.

6. Kaliner MA. Human nasal host defense and sinusitis. J Allergy Clin Immunol 1992; 90:424-30.

7. Hamory BH, Sande MA, Sydnor A, Seale DL, Gwaltney JM. Etiology and antimicrobial therapy of acute maxillary sinusitis. J Infect Dis 1979; 139:197-202.

8. Wald ER, Byers C, Guerra N, Casselbrant M, Beste D. Subacute sinusitis in children. J Pediatr 1989; 115:28-32.

9. Wald ER, Reilly JS, Casselbrant $\mathrm{M}$ et al. Treatment of acute maxillary sinusitis in childhood: A comparative study of amoxicillin and cefaclor. J Pediatr 1994; 104:297-302.

10. Wald ER et al. Sub-acute sinusitis in children. J Pediatr 1989; 115:28-32.

11. Shapiro ED et al. Bacteriology of the maxillary sinuses in patient with cystic fibrosis. J Infect Dis 1982; 146:589-93.

12. Wald ER, Milmoe GJ, Bowen AD, Medina JL, Salamon $\mathrm{N}$, Bluestone CD. Acute maxillary sinusitis in children. N Engl J Med 1981; 304:749-54.

13. Slavin RG, Cannon RE, Friedman WH et al. Sinusitis and bronchial asthma. J Allergy Clin Immunol 1980; 66:250-7.

14. Gottlieb MJ. Relation of intranasal disease in the production of bronchial asthma. JAMA 1925; 85:105. Dikutip dari Reid MJ. Complicating features of asthma. Pediatr Clin North Am 1992; 39:1327-41.

15. Harlin SL, Ansel DG, Lane SR et al. A clinical and pathologic study of chronic sinusitis: the role of the eosinophil. J Allergy Clin Immunol 1988; 81:867-75.

16. Rachelefsky GS, Katz RM, Siegel SC. Chronic sinus disease with associated reactive airway disease in children. Pediatrics 1984; 73:526-9.

17. Said M. Penatalaksanaan sinobronkitis pada anak. Dalam: Rahajoe NN, Said M, Ghazali MV. Penyunting Naskah lengkap beberapa masalah klinis praktis pulmonologi anak. Jakarta: BP-FKUI 1988:37-51.

18. Arruda LK, Mimica IM, Sole D et al. Abnormal maxillary sinus radiographs in children: do they represent bacterial infection? Pediatrics 1990; 85:553-8.

19. Nu'man D. Gambaran klinis dan hasil pengobatan sinobronkritis pada anak berumur 4-13 tahun di Bagian IKA-RSCM. Skripsi Bagian Ilmu Kesehatan Anak FKUI 1985:40

20. Siregar SP. Sinusitis menahun pada anak. Maj Kesehatan Masyarakat Indonesia 1996; 8:536-41.

21. Meltzer EO, Orgel HA, Backhaus JW et al. Intranasal flunisolide spray as an adjunct to oral antibiotic therapy for sinusitis. J Allergy Clin Immunol 1993; 92:812-23.

22. Cook PR, Nishioka GJ. Allergic rhinosinusitis in the paediatric population. Otrolaryngol Clin North Am 1996; 35:39-56.

23. Wald ER. Diagnostic considerations. J Pediatr Infect Dis 1985 ; 4:561-3

24. Wald ER. Medical management of sinusitis in pediatric patient. Dalam: Lusk RP Penyunting Pediatric sinusitis. New York: Raven Press 1992: p.71-5.

25. Lusk RP. Surgical management of chronic sinusitis. Dalam: Lusk RP. Penyunting: Pediatric sinusitis. New York: Raven Press 1992:77-91.

26. Pang YT, Willatt DJ. Do antral washout have a place in the current management of chronic sinusitis? J Laryngol Otol 1996; 110:926-8.

27. Parson DS. Chronic sinusitis: a medical or surgical disease? Otolaryngol Clin North Am 1996; 29:1-9.

28. Henriksson G et al. A 13 year report on childhood sinusitis: clinical presentations, predisposing factors and possible means of prevention. Rhinology 1996; 34(3):171-5.

29. Ikeda $\mathrm{K}$ et al. Restoration of the mucociliary clearence of the maxillary sinus after endoscopic sinus surgery. J Allergy Clin Immunol 1997; 99:48-52.

30. Lanza DC et al. Current concepts in the surgical management of chronic and recurrent acute sinusitis. J Allergy Clin Immunol 1992:505-11. 